\title{
A university campus in peri-urban Accra (Ghana) as a haven for dry-forest species
}

\begin{abstract}
Dietmar Simmering, Solomon Addai, Gunther Geller, Annette Otte
Summary: Valley View University (VVU) is a private university located within the dry forest zone of the Accra plains; an area strongly affected by urban sprawl. The campus covers approx. 105 ha. Considerable portions of it are yet undeveloped and covered with savannah thickets. In 2002, the university has committed itself to become Africa's first 'ecological university'. In the context of two projects, substantial improvements have been made in terms of sanitation, water supply, energysaving buildings and organic agriculture. The further development of the campus was designed in a detailed 'ecological masterplan'. In this context, we carried out a floristic inventory of the savannah thickets and found more than 100 plant species; the majority of which represent the species pool of the unique mixture of dry forest and savannah thicket species, which is typical for the region. As the remainder of dry forests and savannah thickets in the Accra plains become increasingly threatened by urban sprawl and overgrazing, the VVU administration has agreed to preserve the species-rich thickets. This is a valuable contribution to a more sustainable development of the region.
\end{abstract}

Key words: dry-forest vegetation, green campus, land use change, species diversity, sustainable development, Sub-Sahara Africa.

\section{UN CAMPUS UNIVERSITAIRE DANS LA ZONE PÉRI-URBAINE D'ACCRA (GHANA) COMME UN REFUGE POUR LES ESPÈCES DE FORÊT SĖCHE}

Résumé: Valley View University (VVU) est une université privée située dans la zone de forêt sèche des plaines d'Accra; une zone fortement affectée par l'expansion urbaine. Le campus couvre approximativement 105 ha. Des parties importantes de celui-ci sont encore peu développées et couvertes de fourrées de savane. En 2002, l'université s'est engagée à devenir la première «université écologique» d’Afrique. Dans le cadre de deux projets, des améliorations substantielles ont été apportées en matière d'assainissement, d'approvisionnement en eau, de bâtiments peu consommateurs d'énergie et d'agriculture biologique. Le développement ultérieur du campus a été conçu dans un «schéma directeur écologique» détaillé. C’est dans ce contexte, que nous avons réalisé un inventaire floristique des fourrées de savane et avons trouvé plus de 100 espèces végétales; dont la majorité représente le pool est composé uniquement d'espèces de forêt sèche et de fourrées de savane, typiques à la région. Comme le reste des forêts sèches et des fourrés de savane des plaines d'Accra deviennent de plus en plus menacées par l'expansion urbaine et le surpâturage, l'administration VVU a accepté de préserver les fourrés riches en espèces. C'est une précieuse contribution à un développement plus durable de la région.

Mots clés: Végétation de forêt sèche, campus vert, mode d'utilisation des terres, diversité spécifique, développement durable, Afrique sub-saharienne.

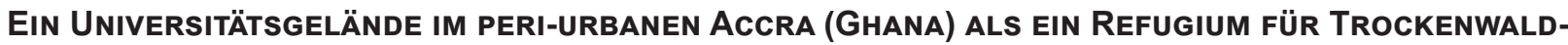 ARTEN}

Zusammenfassung: Die Valley-View Universität (VVU) ist eine private Universität, die in der Trockenwaldzone der Accra Plains liegt; einem Gebiet, welches sehr stark von Urbanisierung und Zersiedlung betroffen ist. Das Campus-Gelände umfasst ca. 105 ha. Beachtliche Flächen davon sind bislang nicht bebaut und noch mit Savannengebüschen bedeckt. Im Jahre 2002 hat sich die VVU zum Ziel gesetzt, die erste „ökologische Universität“ Afrikas zu werden. Im Rahmen zweier Projekte wurden bedeutende Fortschritte im Abwassersystem und der Wasserversorgung sowie beim Bau energiesparender Gebäude und der ökologischen Landwirtschaft erzielt. Die weitere konzeptionelle Entwicklung des Campus wurde in einem detaillierten „Ökologischen Masterplan“ festgehalten. In diesem Rahmen führten wir eine floristische Bestandserhebung in den Savannengebüschen durch und fanden mehr als 100 Pflanzenarten. In der Mehrzahl handelte es sich dabei um den Artenpool der für die Region typischen Kombination aus Trockenwald- und Savannenarten. Da die verbliebenen Reste von Trockenwäldern und Savannengebüschen in den Accra Plains zunehmend durch (ungeplante) Zersiedlung und Überbeweidung bedroht sind, hat die VVU-Verwaltung sich bereit erklärt, die artenreichen Gebüsche auf dem Campus-Gelände zu erhalten. Sie leistet damit einen wertvollen Beitrag zu einer etwas nachhaltigeren Entwicklung der Region.

Schlagworte: Trockenwald-Vegetation, Grüner Campus, Landnutzungswandel, Artenvielfalt, nachhaltige Entwicklung, SubSahara Afrika

\section{INTRODUCTION}

\subsection{Peri-urban sprawl and human ecosystems}

The increasing spread of peri-urban areas in the vicinity of metropolitan cities in many emerging and developing countries is often accompanied by social, societal and environmental problems (REDMAN \& Jones 2005). Severe impacts on human welfare arise from the shortcomings in urban infrastructure and the accelerating environmental degradation, which are usually the results of unplanned, often illegal peri-urban spread. The negative impacts of unplanned, rapid urbanization are a consequence of the population growth due to migration from more remote rural areas, paired with ineffective urban gover- 
nance. Already today, $50 \%$ of the global population live in urban settings and the growth of peri-urban areas will expand to harbor $70 \%$ of the global population by 2050 ; and most urban growth will occur in developing and emerging countries (United NATIONS 2010). Environmental and social problems related to the rapidly increasing urban sprawl are particularly evident in Sub-Saharan West Africa, such as around the major cities in Ghana (YANKSON \& GougH 1999; Gough \& YanKson 2000; YeboAh 2000, 2003; CobBInAH \& AмOAKo 2013).

The land consumption in former rural areas due to these rapid urbanization processes leads to the exacerbation of landuse conflicts between agricultural needs and residential development, whereas both competing land-use types usually have also adverse effects on the biodiversity of natural (or semi-natural) habitats (VITOUSEK et al. 1997). In addition to improvements in urban governance and planning, enormous efforts are needed to make the necessary progress towards sustainable development of peri-urban environments and landscapes. Most urgently needed are solutions for the fundamental social and economic problems of urban sprawl, but the increasing negative impacts on the biodiversity of previously rural landscapes have to be simultaneously taken into account if the important ecological services and functions provided by natural and semi-natural habitats are not to be compromised.

The consideration of the 'multifunctionality' of landscapes aims to integrate ecological and economic aims of land use (OtTe et al. 2007; WALDhARDT et al. 2010). The concept also has potential to cope with the challenges of peri-urban development. According to Selman (2009) 'land is capable of serving more than one purpose and of fulfilling several needs at the same time. Thus, on the same area of land, key functions - ecological, economic, sociocultural, and aesthetic-can be promoted simultaneously and to mutual benefit'. The simultaneous consideration of economic, environmental and cultural goals is without doubt challenging, but could be assured by the involvement of ecological knowledge and guidelines at all stages of planning and development of 'human ecosystems' (LyLE \& WoOdWARd 1999; StepP et al. 2003; LOVELL \& JOHNSTON 2009).

\subsection{Ecological development at Valley View University}

In this context, the aim of this paper is to report on a positive example of sustainable development. The highlighted ecological development of a university campus in Ghana includes the preservation of highly threatened, species-rich savannah thickets in a peri-urban environment.

The private Valley View University (VVU) is located in the peri-urban outskirts of Accra, capital of Ghana. The university, which is operated by the Seventh Day Adventists church, has a spacious property of 105 ha, which comprises settlement areas, public green space, large agricultural plantations, and larger parts of undeveloped 'bushland'. Currently there are around 3,500 people working and studying on campus. This number is expected to grow up to 5.000 in a few years.

In 2002, the university has committed itself to become Africa's first 'ecological university'. In the context of two projects funded by German Federal ministries from 2003 - 2010, concepts and various measures were developed, which improved the situation in terms of sanitation and water supply considerably and led to the construction of energy-saving green buildings and the implementation of organic agriculture on campus (GELLER et al. 2006, GERMER et al. 2006). By means of a detailed master plan, the entire campus was designed as a functional and sustainable ecosystem. Details on the design and concepts of these projects were recently published (GELLER \& GLÜCKLICH 2012).

The main objective of our paper, however, is to report on the remarkable species diversity of the savannah thickets, which are part of the campus and which have to be viewed as one of the last remnants of this semi-natural habitat type in periurban Accra (Fig. 1). The preservation of these thickets has become an integral part of the ecological development of the campus.

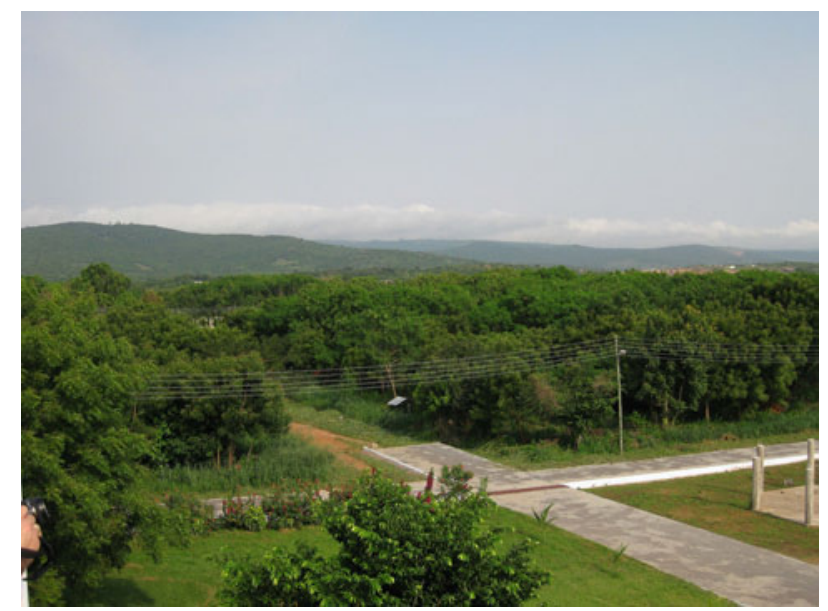

Fig. 1: View from a lecture hall building over the extensive thickets on VVU campus; the Akwapim range in the background. / Vue d'une salle de cours de vastes fourrées sur le campus VVU / Blick von einem Universitätsgebäude über die ausgedehnten Savannengebüsche auf dem VVU-Campus; im Hintergrund der Akwapim-Höhenzug.

\section{The Study AReA}

\subsection{Location and Topography}

Valley View University (VVU) $\left(5.79^{\circ} \mathrm{N}, 0.12^{\circ} \mathrm{W}\right)$ is located $30 \mathrm{~km}$ from downtown Accra - just outside the borders of the Accra Metropolitan District (Fig. 2). The core city, the Accra Metropolitan District, has a population of 1.8 million, while the Greater Accra region is home to 2.9 million people. The Accra region is currently one of the fastest growing urban agglomerations in Africa with a growth rate of more than 3 \% (UNITED NATIONS 2008).

The city is located in the so-called Accra plains. This lowland covers around 2,800 $\mathrm{km}^{2}$ bordered by the Gulf of Guinea to the south, the Akwapim range in the northwest and the Volta River to the east. Here, it merges with the so called Dahomey Gap, which stretches further from SE-Togo to WNigeria. The topography is mostly flat to gently undulating. The altitude is around $80 \mathrm{~m}$ a.s.l. However, only a few kilometers to the west, the Akwapim range rises steeply to an elevation of $400 \mathrm{~m}$. 


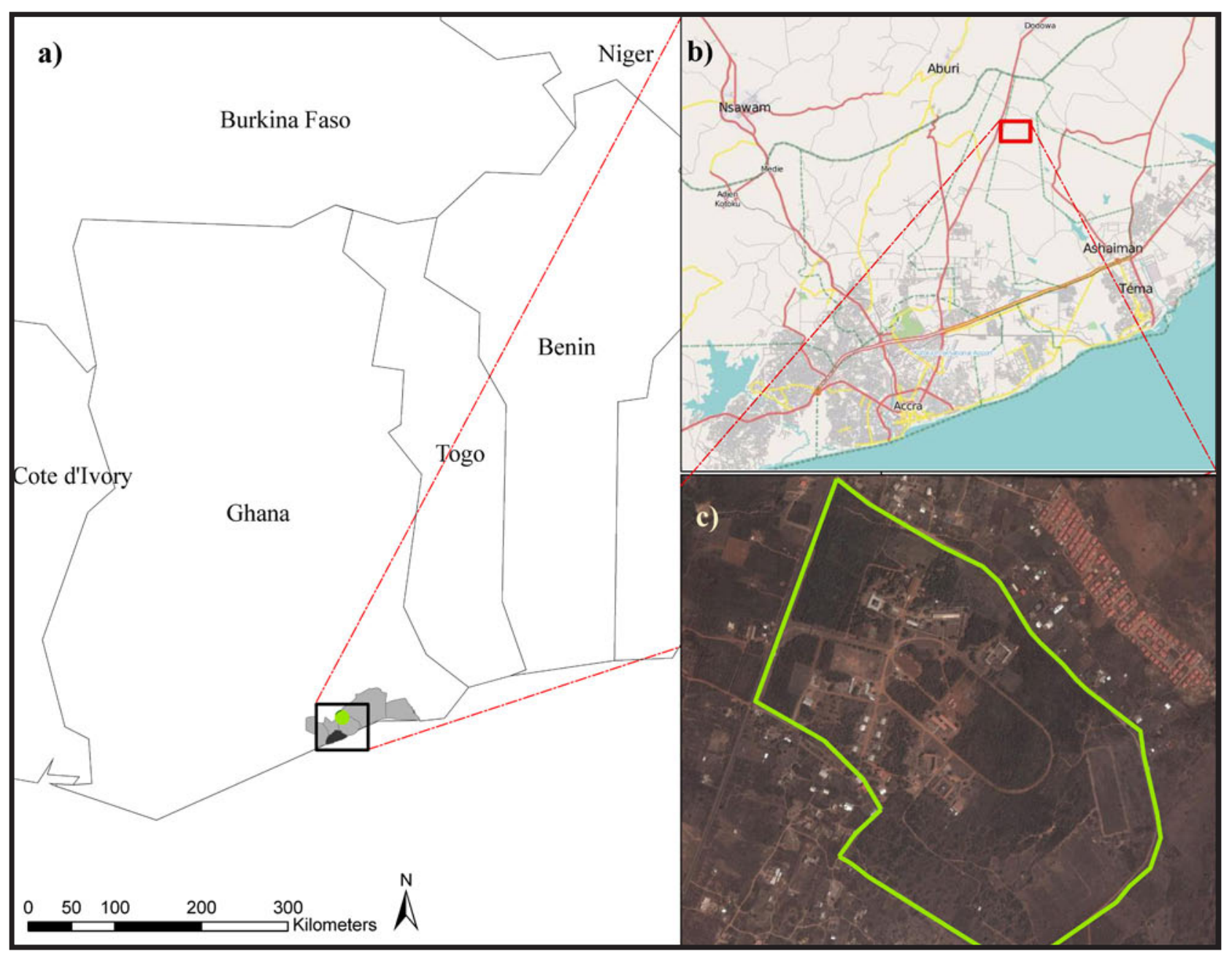

Fig. 2: Location of VVU in peri-urban Accra, Ghana. / Localisation de VVU dans la zone peri-urbaine d'Acrra, Ghana / Lage der Valley View Universität im peri-urbanen Umfeld Accras (Ghana). /

a) The Accra Metropolitan District (black) in the south of Ghana, and the Greater Accra Region (grey); b) The location of VVU on the road to Dodowa; c) VVU campus, the green line indicates the border of the property (neighboring fast developing residential housing areas). /

a) Le distric metropolitain d'Accra (en noir) au sud du Ghana, et la grande région d'Accra (en gris); b) La localisation de VVU sur la route de Dodowa; c) Le campus VVU, la ligne verte indique la limite de la propriété (développement rapide contigu des zones résidentielles). /

a) Der Accra-Metropol-Bezirk (schwarz) im Süden Ghanas und die „Greater Accra Region“ (schwarz); b) Die Lage der VVU an der Straße nach Dodowa, c) Der VVU-Campus, die grüne Linie zeigt die Grenze des Geländes (in der Nachbarschaft sich schnell ausbreitender Wohnsiedlungen).

\subsection{Climate}

The climate in the Plains is known as the Ghana dry zone or the Accra-Togo coastal climate. The Accra plains and the Dahomey Gap represent a discontinuity in the West African (Guinean) forest zone with unique climatic conditions. Accra receives only $780 \mathrm{~mm}$ rainfall, which is not sufficient to support rainforests typical of the neighboring Upper and Lower Guinea forest zones with rainfalls between 1300 - 5000 $\mathrm{mm}$. To illustrate the steep climatic and ecological gradient: Aburi Botanical Garden, on the top of the Akwapim range and only $7 \mathrm{~km}$ away from VVU, receives $1,200 \mathrm{~mm}$; VVU, in contrast, gets even less rain $(700 \mathrm{~mm})$ than Accra due to its location in the rain shadow of the Akwapim range.

The precipitation is distributed among the two rainy seasons (May - Mid-July, Mid-August - October) and falls often in short but intensive terms, which frequently causes local flooding. During the rainy season, monthly precipitation is between 50 and $150 \mathrm{~mm}$. The period between December and
March is especially dry, with monthly total rainfall ranging from 0 to $50 \mathrm{~mm}$. Despite this seasonality, the amount of rainfall is highly variable from year to year. The mean annual temperature is $26.5^{\circ} \mathrm{C}$. Monthly averages range between 24.5 (August) and $28^{\circ} \mathrm{C}$ (March), and the average temperature during the day is $30^{\circ} \mathrm{C}$. Humidity is high in general (65 - 95\%), but is lower during the warmer months, particularly in January with its dry northeast 'harmattan' winds.

\subsection{Natural and secondary vegetation}

The Accra plains are an ancient cultural landscape, inhabited and formed by humans for 6,000 years. The dominating soils in the region are savannah ochrosols and regosolic groundwater laterites over acidic and basic Gneiss and Shists rocks (BRAMmER 1962). The reddish, brown and yellow sandy-to-loamy soils are generally shallow and prone to erosion. Organic matter content and nutrient status is low. However, plant growth is even more impeded by the poor physical properties of the droughty soils. Crops grown in the area without irrigation have to be drought resistant. There- 
fore, a grassland savannah, traditionally grazed by cattle and regularly burned, is still the predominating vegetation and land-use type in the Accra plains.

Savannah grasslands and thickets were the most common vegetation types in this area prior to recent urbanization. However, the savannah in the Accra plains is considered a 'subclimax vegetation', a 'derived savannah'. The natural vegetation of the Accra plains is a dry semi-deciduous forest of various types, the most unique type being the "southeast outlier type" described by HaLl \& SwaIne (1976) from the nearby Shai Hills reserve. This forest type represents the driest extreme in Ghana. The vertical structure features a closed canopy composed of mainly Millettia thonningii and Diospyros sp. that reaches only $15 \mathrm{~m}$ in height, while Dryopetes parviflora, Vepris heterophylla and numerous savannah thicket and liana species form a $10 \mathrm{~m}$ understorey. Ground cover is sparse. Scattered emergent trees tower up to $50 \mathrm{~m}$ above the canopy (Ceiba pentandra, among others). The remaining stands of this forest type are today restricted to scattered, very small reserves.

The original dry forest cover of the Accra plains has been turned into savanna by continuing human impact over the millennia. Regular burning, grazing, firewood cutting, charcoaling and rotation farming have maintained a savannah mosaic with varying proportions of grass and thicket cover. Regular disturbance prevents the development of forest.

\subsection{Land-use history on VVU campus}

The Valley View College, which was to become Valley View University in 1997, moved from a former urban location to its current site near the village of Oyibi in 1989 According to local traditions in land tenure, it was leased out for 99 years (Owusu-Mensa 2009). At that time, the land was composed of savannah thickets and farmland, including fallow land. This pattern of land cover was typical for the rural areas surrounding Accra. Some parts of the property were at that time also still covered with tall KyenKyen trees (Bark cloth tree, Antiaris toxicaria Lesh., Moraceae), which are characteristic for the native dry-forests of the Accra plains. Until the trees were felled in the 1990's, monkeys fed on them and inhabited the area, even after the university had opened the doors. However, at the beginning of the ecological projects in 2003, large areas of the property had not been managed at all, except for a few buildings, some roads and agricultural land. The 'bushland' was regarded by the students as hostile 'wilderness', whereas for rural dwellers the freely accessible land was an important source of firewood and charcoal, which was also regularly burned, and grazed by cattle.

\section{Methods}

A floristic inventory of the savannah thickets at VVU was carried out in May 2009 with the support of experts on the Ghanaian flora. The species were photographed and specimens were collected for two herbaria stored at VVU and at Giessen University. The works of Hutchinson \& Dalziel (1954-1972), Irvine (1961), ArbonNiER (2004) and HawTHORNE \& JONGKIND (2006) were used for plant identification. These references and LiEBERman (1982) were also used to assign the plant functional type (tree, shrub, liana, herb, graminoid) and the Raunkiær Life forms. The phanerophytes were sub-grouped according to height as follows: nano- (less than 2m), micro- (2-8 m), meso- (8-30 m), and mega-phanerophytes (more than $30 \mathrm{~m}$ ).

Information on the rarity of medicinal plants was taken from AввIw (no year, 1990). The evaluation of the conservation value was based on expert knowledge on the local distribution of plant species (Abbiw, pers. communication) as well as on literature review. Nomenclature follows the online 'African Plants Database' (2013), based and maintained at the Geneva Botanical Garden.

\section{Results AND Discussion}

\subsection{Floristic survey and evaluation}

In total, 108 plant species from 51 families were found in the thickets (Tab. 1). Families with more than three representatives were: Poaceae (9), Fabaceae (8), Rubiaceae (8), Euphorbiaceae (6) and Asclepidiaceae (5).

However, the woody species of various families dominated the dense savannah thickets. Characteristic and frequent species were Albizia zygia, Dialium guineense, Baphia nitida, B. pubescens, Gardenia ternata, Grewia carpinifolia, Griffonia simplicifolia, Lannea acida, Millettia thonningii, Paullinia pinnata, Philenoptera cyanescens, Sarcocephalus latifolius, Uvaria chamae, U. ovata, Tapinanthus globiferus, Zanthoxylum zanthoxyloides (Fig. 3a-f).

Overall, we found 27 tree species, 26 shrub species, 26 lianas (including climbing shrubs, herbs and parasites), 18 (woody) herbs, and 11 graminoids. Phanerophytes represent the dominant life-form with $49 \%$ of all species, the largest subgroup being medium sized shrubs and small trees (micro-phanerophytes, 2 - 8 m height) with 33 species (Fig. 4).

Ninety-six species have to be considered as native to the Accra plains and typical of the wooded savannahs in the Guinean zone, while 12 species are widespread tropical species that have become naturalized in the region. Among these are a number of invasive dominant species (see below). Many of the native species are traditionally used as medicinal plants. Twenty-seven species found in the thickets are regarded as 'endangered medicinal plants' on a regional scale. Most of them are rare due to habitat destruction and overexploitation for medicinal purposes (AвBгw 1990, no year).

The flora and vegetation of the thickets and grass savannah of the Accra plains have been studied by a number of authors. JENíK \& HALL (1976) state in their comprehensive phytosociological study that, although mainly comprised of species native to the Guinean zone, the grassland and thicket communities found in the Accra plains are unique in the context of tropical African vegetation. HALL \& SwAINE $(1976,1981)$ reported the total remaining area of the typical dry-forest type of the plains at $20 \mathrm{~km}^{2}$ in small scattered patches. It has to be assumed that, after 30 years of peri-urban development, this area is much smaller today. The authors also emphasize the structural and floristic distinctiveness of these forests, which is founded in the relative paucity of 
Table 1: List of species found in the VVU-thickets / Liste des espèces trouvées dans les fourrées de VVU/ Artenliste der Savannnengebüsche auf dem VVU-Campusgelände.

Abbreviations / Abbreviations / Abkürzungen:

PFT = Plant functional type / Type fonctionnel des plantes / Funktionelle Gruppe

LF = Life form type / Type biologique / Lebensform

Pinkwae = species occurring in the neighboring Pinkwae sacred-grove according to LiEBERMAN (1982) / Espèces se développant dans le voisinage de la grotte sacrée de Pinkwae selon Lieberman (1982) / nach Lieberman (1982) im benachbarten "Heiligen Hain” Pinkwae vorkommende Arten.

End. Med: endangered medicinal plants according to AвBıw (no year) / Plantes médicinales menacées selon AвBıw (sans date) / gefährdete Heilpflanzen nach ABBiw (ohne Jahr).

Inv. Species = non-native, invasive species / exotiques, espèces invasives / gebietsfremde, invasive Arten.

nn-P: nano-phanerophyte $(<2 \mathrm{~m})$, mc-P: micro-phanerophyte (2-8 m), ms-P: meso-phanerophyte (8-30 m), mg-phanerophyte (> 30m).

\begin{tabular}{|c|c|c|c|c|c|c|}
\hline Name & Family & PFT & LF & Pinkwae & End. Med. & Inv. Species \\
\hline Ruspolia hypocrateriformis & Acanth. & shrub & nn-P & $\mathrm{x}$ & & \\
\hline Crinum ornatum & Amaryllid. & herb & $G$ & $\mathrm{x}$ & & \\
\hline Scadoxus multiflorus & Amaryllid. & herb & $\mathrm{G}$ & $\mathrm{x}$ & & \\
\hline Lannea acida & Anacardi. & tree & mc-P & $\mathrm{x}$ & & \\
\hline Lannea barteri & Anacardi. & tree & ms-P & & $\mathrm{x}$ & \\
\hline Annona senegalensis & Annon. & shrub & mc-P & $\mathrm{x}$ & & \\
\hline Uvaria chamae & Annon. & shrub & mc-P & $\mathrm{x}$ & $\mathrm{x}$ & \\
\hline Uvaria ovata & Annon. & shrub & nn-P & & & \\
\hline Carissa spinarum & Apocyn. & shrub & mc-P & $\mathrm{x}$ & $\mathrm{x}$ & \\
\hline Holarrhena floribunda & Apocyn. & tree & ms-P & & & \\
\hline Hunteria umbellata & Apocyn. & shrub & ms-P & & $\mathrm{x}$ & \\
\hline Anchomanes difformis & Arac. & herb & $\mathrm{H}, \mathrm{G}$ & $\mathrm{x}$ & & \\
\hline Cynanchum viminale & Asclepiad. & liana & li & $\mathrm{x}$ & & \\
\hline Gymnema sylvestre & Asclepiad. & climbing shrub & mc-P, li & & $\mathrm{x}$ & $\mathrm{x}$ \\
\hline Leptadenia hastata & Asclepiad. & liana & li & & & \\
\hline Pergularia daemia & Asclepiad. & climbing herb & T, li & & & \\
\hline Secamone afzelii & Asclepiad. & liana & li & $\mathrm{x}$ & $x$ & \\
\hline Asparagus warneckei & Asparag. & climbing herb & $\mathrm{H}$, li & $\mathrm{x}$ & & \\
\hline Chromolaena odorata & Aster. & climbing herb & H, li & & & $\mathrm{x}$ \\
\hline Tridax procumbens & Aster. & herb & $\mathrm{T}$ & & & $\mathrm{x}$ \\
\hline Vernonia colorata & Aster. & shrub & mc-P & $\mathrm{x}$ & & \\
\hline Adansonia digitata & Bombac. & tree & mg-P & $\mathrm{x}$ & & \\
\hline Ceiba pentandra & Bombac. & tree & mg-P & $\mathrm{x}$ & $\mathrm{x}$ & \\
\hline Ehretia cymosa & Boragin. & climbing shrub & mc-P, li & $\mathrm{x}$ & & \\
\hline Dialium guineense & Caesalpini. & tree & ms-P & $\mathrm{x}$ & & \\
\hline Griffonia simplicifolia & Caesalpini. & climbing shrub & mc-P, li & $\mathrm{x}$ & & \\
\hline Senna occidentalis & Caesalpini. & shrub & nn-P & & & \\
\hline Capparis erythrocarpos & Cappar. & climbing shrub & mc-P, li & $\mathrm{x}$ & $\mathrm{x}$ & \\
\hline Gymnosporia senegalensis & Celastr. & tree & mc-P & $\mathrm{x}$ & $\mathrm{x}$ & \\
\hline Gloriosa superba & Colchic. & climbing herb & G, li & & & $\mathrm{x}$ \\
\hline Commelina erecta & Commelin. & (subwoody) herb & $\mathrm{H}, \mathrm{C}$ & $\mathrm{x}$ & & \\
\hline Cnestis ferruginea & Connar. & climbing shrub & mc-P, li & & & \\
\hline Rourea coccinea & Connar. & shrub & nn-P & $\mathrm{x}$ & $\mathrm{x}$ & \\
\hline Evolvulus alsinoides & Convolvul. & herb & $\mathrm{H}$ & & & \\
\hline Mariscus cylindristachyus & Cyper. & graminoid & $\mathrm{H}$ & & & \\
\hline Scleria sp. & Cyper. & graminoid & $\mathrm{H}$ & & & \\
\hline Dichapetalum madagascariense & Dichapetal. & tree & ms-P & & & \\
\hline Dracaena surculosa & Dracaen. & liana & li & $\mathrm{x}$ & & \\
\hline
\end{tabular}




\begin{tabular}{|c|c|c|c|c|c|c|}
\hline Name & Family & PFT & LF & Pinkwae & End. Med. & Inv. Species \\
\hline Sansevieria liberica & Dracaen. & (subwoody) herb & $\mathrm{H}, \mathrm{C}$ & $\mathrm{x}$ & & \\
\hline Diospyros mespiliformis & Eben. & tree & ms-P & $\mathrm{x}$ & & \\
\hline Bridelia ferruginea & Euphorbi. & tree & mc-P & $\mathrm{x}$ & & \\
\hline Erythrococca anomala & Euphorbi. & shrub & nn-P & & $\mathrm{x}$ & \\
\hline Flueggea virosa & Euphorbi. & shrub & mc-P & & & \\
\hline Jatropha gossypiifolia & Euphorbi. & shrub & nn-P & $\mathrm{x}$ & & $\mathrm{x}$ \\
\hline Mallotus oppositifolius & Euphorbi. & shrub & mc-P & $\mathrm{x}$ & & \\
\hline Tragia benthamii & Euphorbi. & shrub & mc-P & $\mathrm{x}$ & & \\
\hline Abrus precatorius & Fab. & liana & li & $\mathrm{x}$ & $\mathrm{x}$ & $\mathrm{x}$ \\
\hline Baphia nitida & Fab. & tree & mc-P & $\mathrm{x}$ & & \\
\hline Baphia pubescens & Fab. & shrub & mc-P & $\mathrm{x}$ & & \\
\hline Millettia thonningii & Fab. & tree & $\mathrm{ms}-\mathrm{P}$ & $\mathrm{x}$ & & \\
\hline Philenoptera cyanescens & Fab. & climbing shrub & mc-P, li & $\mathrm{x}$ & & \\
\hline Pterocarpus erinaceus & Fab. & tree & ms-P & & & \\
\hline Stylosanthes erecta & Fab. & (subwoody) herb & $\mathrm{H}, \mathrm{C}$ & & & \\
\hline Uraria picta & Fab. & (subwoody) herb & $\mathrm{H}, \mathrm{C}$ & & $\mathrm{x}$ & \\
\hline Dovyalis sp. & Flacourti. & shrub & nn-P & & & \\
\hline Flacourtia indica & Flacourti. & shrub & mc-P & $\mathrm{x}$ & & \\
\hline Hoslundia opposita & Lami. & shrub & nn-P & $\mathrm{x}$ & $\mathrm{x}$ & \\
\hline Cassytha filiformis & Laur. & herb (parasitic) & $\mathrm{H}, \mathrm{pa}$ & & & \\
\hline Tapinanthus globiferus & Loranth. & parasitic climber & li, pa & & & \\
\hline Acridocarpus smeathmanii & Malphigi. & climbing shrub & mc-P, li & $\mathrm{x}$ & $\mathrm{x}$ & \\
\hline Abutilon mauritianum & Malv. & (subwoody) herb & $\mathrm{H}, \mathrm{C}$ & & & \\
\hline Sida acuta & Malv. & herb & $\mathrm{T}, \mathrm{H}$ & & & $\mathrm{x}$ \\
\hline Sida linifolia & Malv. & (subwoody) herb & $\mathrm{H}, \mathrm{C}$ & & $\mathrm{x}$ & \\
\hline Azadirachta indica & Meli. & tree & $\mathrm{ms}-\mathrm{P}$ & $\mathrm{x}$ & & $\mathrm{x}$ \\
\hline Cissampelos mucronata & Menisperm. & liana & li & & & \\
\hline Triclisia subcordata & Menisperm. & liana & li & $\mathrm{x}$ & & \\
\hline Albizia zygia & Mimos. & tree & ms-P & & $\mathrm{x}$ & \\
\hline Dichrostachys cinerea & Mimos. & shrub & mc-P & $\mathrm{x}$ & & \\
\hline Leucaena leucocephala & Mimos. & tree & ms-P & & & $\mathrm{x}$ \\
\hline Antiaris toxicaria & Mor. & tree & mg-P & $\mathrm{x}$ & $\mathrm{x}$ & \\
\hline Ochna membranacea & Ochn. & tree & mc-P & $\mathrm{x}$ & & \\
\hline Ximenia americana & Olac. & tree & mc-P & $\mathrm{x}$ & $\mathrm{x}$ & \\
\hline Jasminum dichotomum & Ole. & climbing shrub & mc-P, li & & & \\
\hline Eulophia cristata & Orchid. & herb & G & $\mathrm{x}$ & & \\
\hline Andropogon gayanus & Poac. & graminoid & $\mathrm{H}$ & & & \\
\hline Chloris barbata & Poac. & graminoid & $\mathrm{T}$ & & & \\
\hline Digitaria insularis & Poac. & graminoid & $\mathrm{H}$ & & & $\mathrm{x}$ \\
\hline Eragrostis sp. & Poac. & graminoid & $\mathrm{H}$ & & & \\
\hline Heteropogon contortus & Poac. & graminoid & $\mathrm{T}$ & $\mathrm{x}$ & & \\
\hline Oxytenanthera abyssinica & Poac. & graminoid & ms-P & & & \\
\hline Panicum maximum & Poac. & graminoid & $\mathrm{H}$ & & & \\
\hline Perotis hildebrandtii & Poac. & graminoid & $\mathrm{T}$ & & & \\
\hline Sporobolus pyramidalis & Poac. & graminoid & $\mathrm{H}$ & & & \\
\hline Talinum triangulare & Portulac. & herb & $\mathrm{H}$ & & & $\mathrm{x}$ \\
\hline Crossopteryx febrifuga & Rubi. & tree & mc-P & & & \\
\hline
\end{tabular}




\begin{tabular}{|c|c|c|c|c|c|c|}
\hline Name & Family & PFT & LF & Pinkwae & End. Med. & Inv. Species \\
\hline Gardenia ternifolia & Rubi. & shrub & mc-P & $\mathrm{x}$ & & \\
\hline Morinda lucida & Rubi. & tree & ms-P & & & \\
\hline Oxyanthus racemosus & Rubi. & shrub & nn-P & $\mathrm{x}$ & & \\
\hline Pavetta corymbosa & Rubi. & shrub & $\mathrm{nn}-\mathrm{P}$ & $\mathrm{x}$ & & \\
\hline Psychotria sp. & Rubi. & shrub & mc-P & & & \\
\hline Sarcocephalus latifolius & Rubi. & climbing shrub & ms-P, li & & $\mathrm{x}$ & \\
\hline Vangueriella spinosa & Rubi. & shrub & mc-P & $\mathrm{x}$ & & \\
\hline Afraegle paniculata & Rut. & tree & ms-P & $\mathrm{x}$ & $\mathrm{x}$ & \\
\hline Clausena anisata & Rut. & shrub & mc-P & $\mathrm{x}$ & $\mathrm{x}$ & \\
\hline Zanthoxylum zanthoxyloides & Rut. & tree & ms-P & $\mathrm{x}$ & $\mathrm{x}$ & \\
\hline Allophylus africanus & Sapind. & tree & mc-P & & & \\
\hline Deinbollia pinnata & Sapind. & tree & mc-P & & & \\
\hline Paullinia pinnata & Sapind. & liana & $\mathrm{li}$ & $\mathrm{x}$ & $\mathrm{x}$ & \\
\hline Pouteria alnifolia & Sapot. & tree & mc-P & $\mathrm{x}$ & & \\
\hline Scoparia dulcis & Scrophulari. & (subwoody) herb & $\mathrm{H}, \mathrm{C}$ & & $x$ & \\
\hline Schwenkia americana & Solan. & herb & $\mathrm{T}, \mathrm{H}$ & & & \\
\hline Waltheria indica & Sterculi. & (subwoody) herb & $\mathrm{H}, \mathrm{C}$ & & $x$ & \\
\hline Grewia carpinifolia & Tili. & climbing shrub & mc-P, li & $\mathrm{x}$ & & \\
\hline Trema domingensis & Ulm. & shrub & ms-P & & & \\
\hline Lantana camara & Verben. & climbing shrub & nn-P & $\mathrm{x}$ & & $\mathrm{x}$ \\
\hline Premna quadrifolia & Verben. & liana & li & $\mathrm{x}$ & $\mathrm{x}$ & \\
\hline Vitex doniana & Verben. & tree & $\mathrm{ms}-\mathrm{P}$ & $\mathrm{x}$ & & \\
\hline Cissus sp. & Vit. & liana & li & & & \\
\hline
\end{tabular}

species and high gregariousness among the trees, i.e. the local dominance of single species.

LiebERMAN (1982) and LiEBERMAN \& Li (1992) studied the ecology of the nearby dry forest of the Pinkwae Sacred Grove in Katamanso. In total, fifty species of trees, shrubs and lianas listed by LiEBERMan (1982) for the Pinkwae forest were also found at VVU, indicating the high potential of the thickets to mature to a dry forest, when protected from cutting and burning (cf. Table 1). However, many of the recorded tree species in the VVU thickets were only found in small numbers and / or in juvenile or coppiced individuals. Full-grown trees did not occur at all for most species. This is a consequence of the unauthorized cattle grazing, firewood chopping and charcoaling by rural dwellers, and the frequent fires set by herdsmen and hunters.

Another threat to the species-rich thickets is the continuing spread of dominant introduced species, namely the Neem (Azadirachta indica) and Leucaena (Leucaena leucocephala) trees, as well as the noxious shrubby climbers Siam Weed (Chromolaena odorata) and Spanish Flag (Lantana camara). However, areas mainly occupied by these weeds were located in those areas destined for future development, whereas the 'bushland' containing mainly the Guinean savannah and dry-forest species were located in the destined "green belt" of the campus (Fig. 5).

Due to the increasing urban sprawl with ever-expanding residential areas and an associated overexploitation of natural resources (frequent burning, overgrazing), only very small portions of savannah bushland and natural vegetation are today left in the former rural Accra region. Larger portions of relatively undisturbed savannah thickets and dry forest are only preserved in the mentioned Pinkwae Sacred Grove (Fig. 6) and in the Shai Hills Resource Reserve (Fig. 7). Since even these reserves are endangered by encroachment, the remaining thickets on the VVU campus are obviously very valuable in terms of biodiversity conservation at the regional scale.

\subsection{Project outcome}

Vegetation plays, without doubt, a crucial role in the functioning of human-dominated ecosystems and provides key benefits (ecosystem services) to the human population. The most fundamental of these 'ecosystem services' are the production of biomass as food and energy resource and the release of oxygen. But in human ecosystems, a well-developed plant cover also reduces heat, noise, dust, and serves as a wind break. Furthermore, it increases water infiltration and reduces runoff, thus facilitating flood control and groundwater recharge. Besides these more physical properties of vegetation and their effects on ecosystems, a quality green environment has numerous psychosocial benefits and promotes human wellbeing and health.

The first steps to account for the ecological functions and services provided by the vegetation in the eco-development of VVU were therefore the design of an extended, unspecified 'green belt' in the ecological master plan and the planting of various large tree orchards in the agricultural projects starting in 2003. The campus witnessed a rapid development 

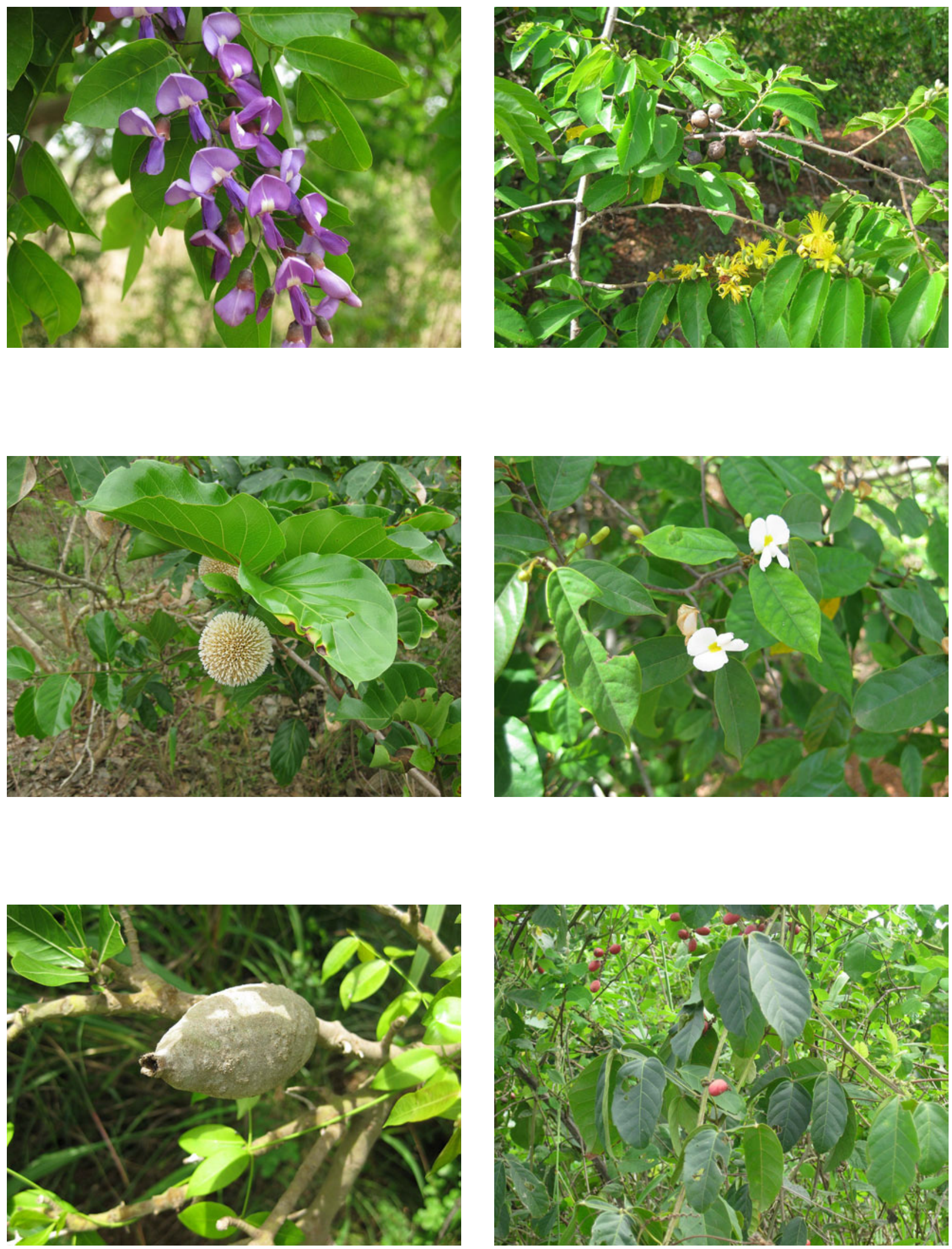

Fig. 3 a-f: Some characteristic species on VVU campus. / Quelques espèces caractéristiques du campus VVU / Einige charakteristische Arten der Gebüsche auf dem VVU-Gelände. a: Millettia thonningii, b: Grewia carpinifolia, c: Sarcocephalus latifolius, d: Baphia nitida, e: Gardenia ternifolia, f: Paullinia pinnata 


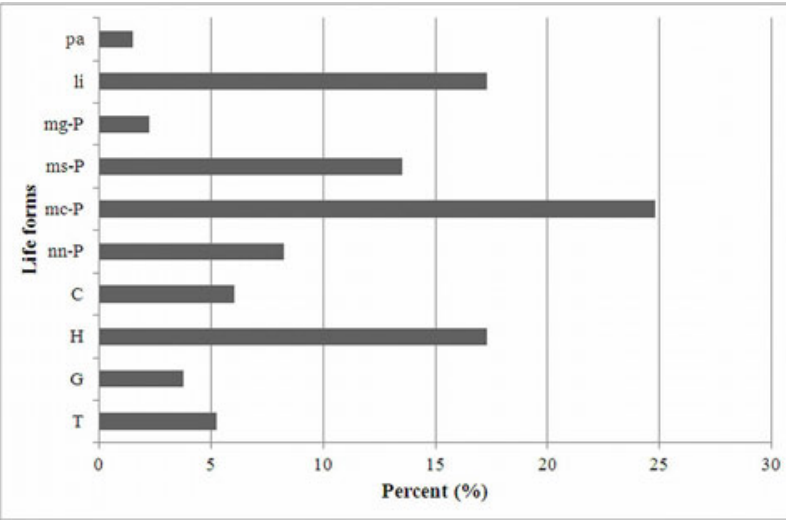

Fig. 4: Life-form spectrum of the thickets. Some species were assigned to more than one life form according to Tab. 1. / Spectre biologique des fourrées. Certaines espèces ont été assignées à plus d'une forme biologique selon le Tableau. 1./ Lebensformenspektrum der Savannengebüsche. Einige Arten wurden mehr als einer Lebensform zugeordnet (siehe Tab. 1).

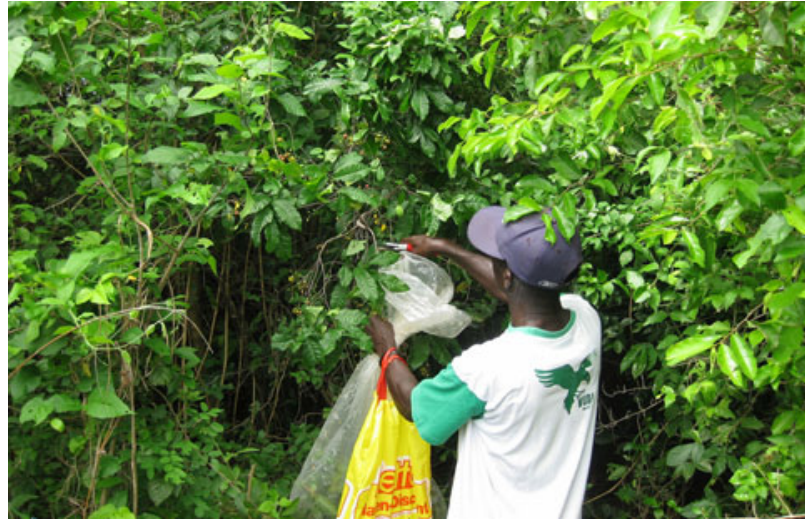

Fig. 5: View into the dense thickets. Botanist R S. Amponsah collecting Ochna membranacea. / Vue des fourrées denses. Collection de Ochna membranacea d'un Botaniste R S. Amponsah./ Blick in das dichte Savannengebüsch. Botaniker R S. Amponsah sammelt Ochna membranacea für das Herbar.

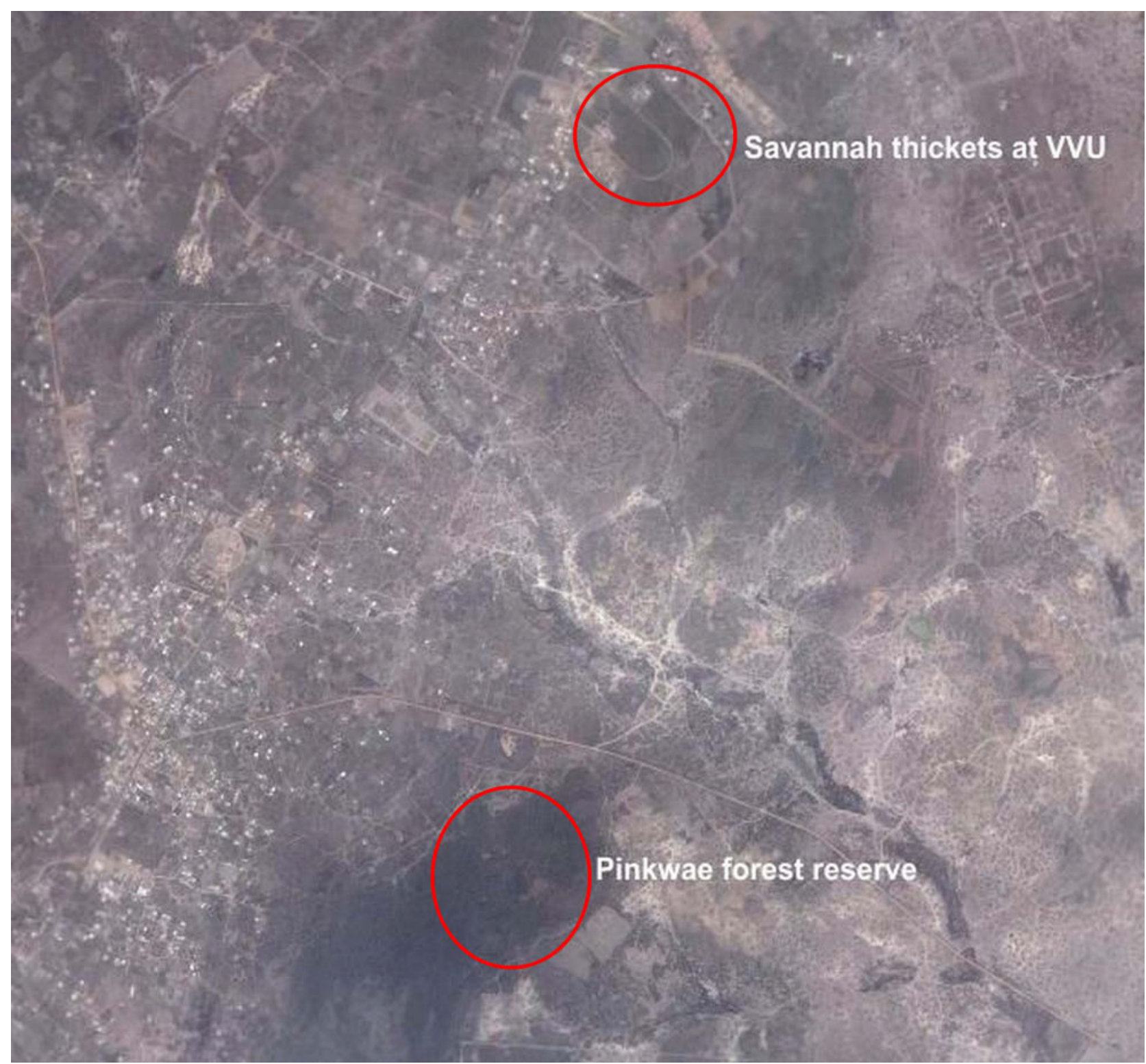

Fig. 6: Satellite image of VVU and Pinkwae sacred grove. Image satellitaire de la grotte sacrée de VVU et Pinkwae

The distance between both sites is $4 \mathrm{~km}$. The dark color indicates the thickets, both are surrounded by overgrazed / burned savannah and fast spreading residential areas. / La distance entre les deux sites est de $4 \mathrm{~km}$. La couleur foncée indique les fourrés, les deux sont entourés par des zones surpâturées/ savane brûlée et expansion rapide des zones residentielles / Satellitenbild des VVU-Geländes und des Heiligen Hains "Pinkwae" in etwa 4 km Entfernung. Die dunkle Farbe kennzeichnet die geschlossenen Gebüsche, beide Gebiete sind von überweideter / gebrannter Savanne und sich schnell ausbreitenden Wohnbebauungen umzingelt. 


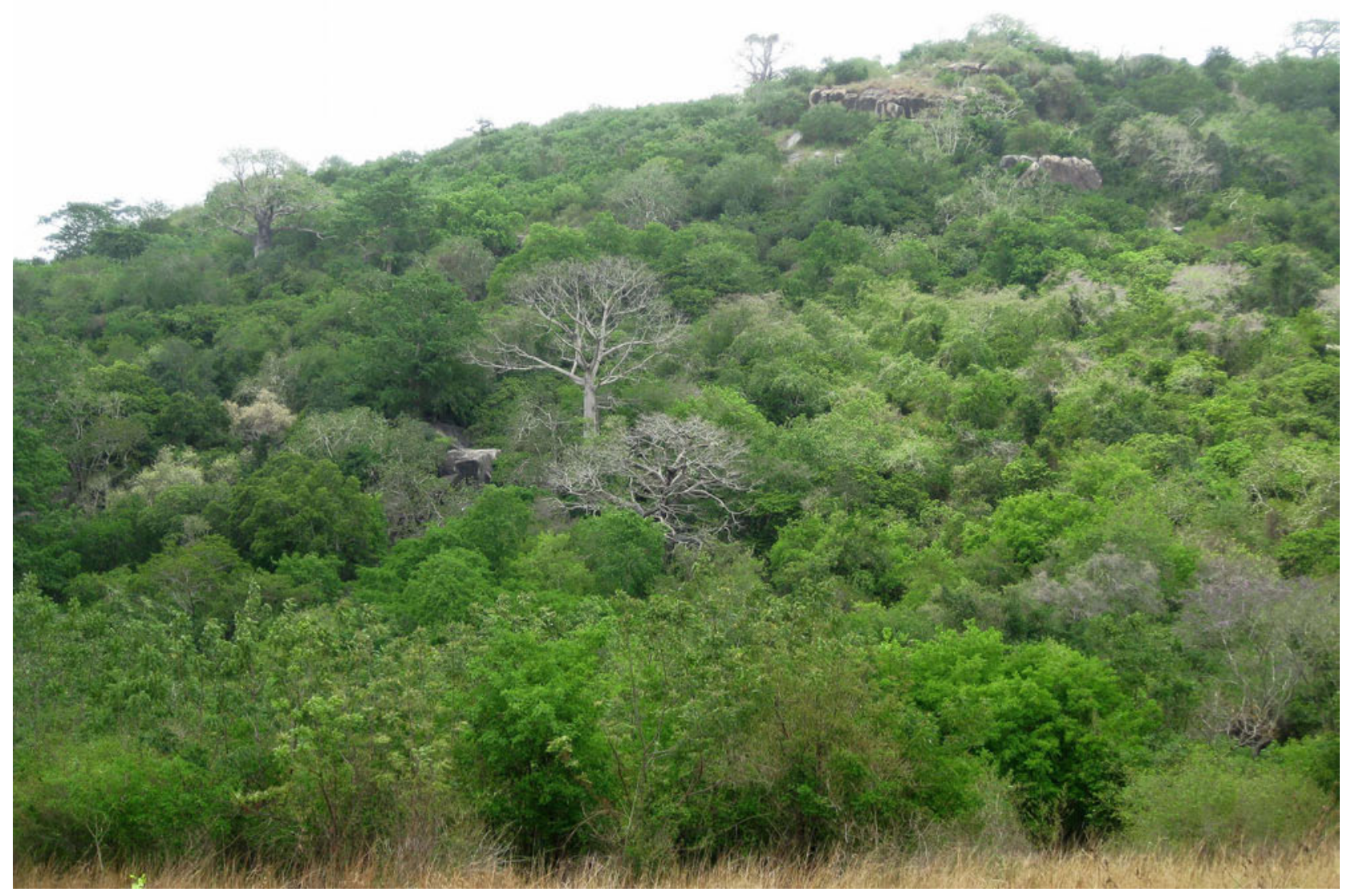

Fig. 7: The largest remaining dry-forest in the Accra plains: Shai Hills Resource Reserve (20 km northeast from VVU) with emergent Kapok (Ceiba pentandra) trees towering over the dense dry forest canopy with flowering Millettia thonningii. / Le plus grand vestige de forêt sèche dans les plaines d'Accra: Reserve de ressources du Mont Shai (20 Km au nord-est de VVU) avec des kapokiers (Ceiba pentandra) emergeant au-dessus de la canopée de la forêt sèche avec Millettia thonningii en floraison. / Der größte noch erhaltene Trockenwald in den Accra Plains: das Shai Hills-Schutzgebiet 20 km nordöstlich der VVU. Einzelne Kapokbäume (Ceiba pentandra) überragen die dichte Baumschicht des Trockenwaldes mit blühenden Millettia thonningii.

of the university, and by 2008, $27 \%$ of the total area were already covered with buildings and associated green space. Another $21 \%$ were used for agriculture, $29 \%$ were awaiting future development and approx. $12 \%$ were reserved for the green belt. During a later stage of the project, the planting of a large numbers of trees (fruit trees, shade trees, ornamentals, but also native tree species in burned areas) was a major focus (GELLER \& GLÜCKLICH 2012).

However, vegetation serves also as habitat for plant and animal species and is thus the foundation of biodiversity. The conservation of biodiversity and a wildlife-friendly management of the remaining semi-natural and natural habitats is therefore an important issue in rural and urban systems. This is particularly important for the last remnants of dry-forest and shrub vegetation in the Accra plains, which are known to harbor a considerable diversity of animal species (e.g., Decher 1997, Decher \& Bahian 1999, CAmpbell 2004).

From the results of the floristic survey, the intent evolved to protect 17 ha of the threatened species-rich bushland on VVU property (Fig. 8). Only slight modifications of the initial planning were necessary to permit the preservation of relevant thicket areas, without compromising the further development of the university according to the master plan.
In 2010, the VVU administration has therefore agreed to exempt the central parts of bushland from further development. In addition, the agricultural department at VVU takes measures for the protection of the thickets from unauthorized firewood chopping and burning. The preservation of the thickets is a significant contribution to preserve the unique mixture of dry-forest species in the Accra plains.

\section{Acknowledgements}

The authors dedicate this paper to the memory of our partner, Professor Dr.-Ing. Detlef Glücklich, who had been one of the creative minds behind the master plan for VVU. Sadly, he passed away in June 2013.

We cordially thank all people and institutions that were part of and supported the projects at Valley View University from 2003 - 2010. We are very grateful for the successful cooperation with the VVU administration. Foremost, we thank former VVU-president Dr. Seth Laryea and the former director of the Physical Plant, Emmanuel Kwandahor, for their enduring support and passion. The support of Prof. J. K. Osei was invaluable to compensate for lack of time in the tree-planting project. We are further indebted to the excellent botanists Daniel K. Abbiw, former curator of the University of Ghana herbarium, and his colleague R.S. Amponsah for their patient help in the field. The project (ZN IÖV Ghana 08_II_023) was funded by the German Ministry for the Environment, Nature Conservation and Nuclear Safety within the International Climate Change Initiative (IKI). 


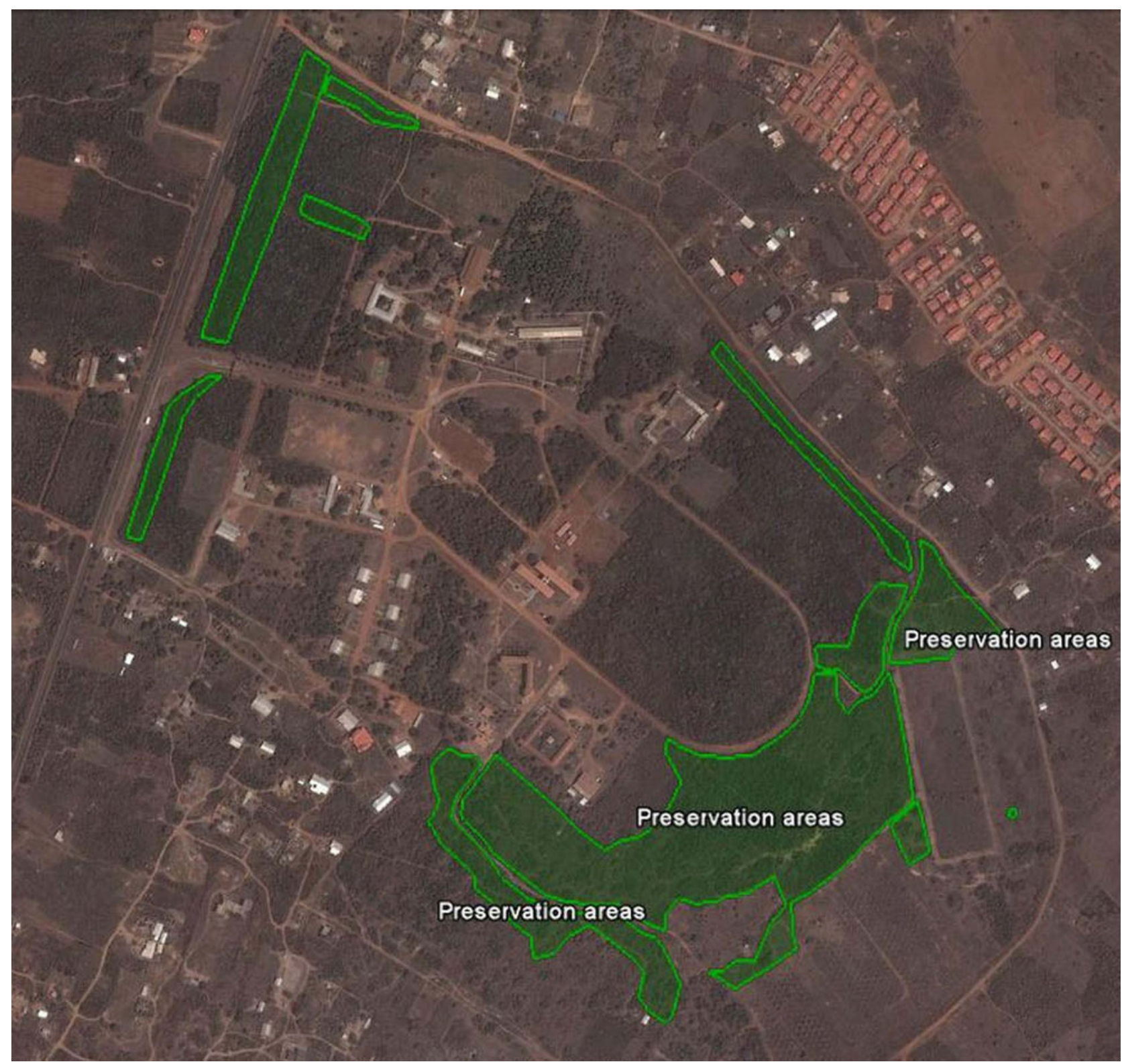

Fig. 8: Designated preservation areas for thicket vegetation on VVU-campus. / Zone reservée à la conservation de la végétation de fourrée sur le campus VVU / Die vorgesehenen Schutzzonen für die Savannengebüsche auf dem VVU-Gelände.

\section{References}

AвBIw DK (1990): The useful plants of Ghana. - Royal Botanic Gardens, Kew, Richmond, Surrey, London / Kew, 337 p.

ABBIw DK (no year): Endangered medicinal plants in the middle and southern sector of Ghana. - Traditional and Alternative Medicine Directorate, Ministry of Health, Accra, $60 \mathrm{p}$.

ArbonNier M (2004): Trees, shrubs and lianas of West African dry zones. - CIRAD-Margraf-MNHN, Wageningen, $576 \mathrm{p}$.

Brammer H (1962): Soils. - in: WiLls JBP (Ed): Agriculture and Land Use in Ghana. - Oxford University Press, London, Accra, New York, 160-169.

CAmpbell MO (2004): Traditional forest protection and woodlots in the coastal savannah of Ghana. - Environ. Conserv. 31: 225-232.
Cobbinah PB \& Amoako C (2013): Urban sprawl and the loss of peri-urban land in Kumasi, Ghana. - Int. J. Soc. Hum. Sci. 03/2012: 388-397.

DeCher J (1997): Conservation, small mammals, and the future of sacred groves in West Africa. Biodivers. Conserv. 6: 1007-1026.

DeCher J \& BAHIAN LK (1999): Diversity and structure of terrestrial small mammal communities in different vegetation types on the Accra Plains of Ghana. J. Zool. 247: 395408.

Geller G, Berger W, Fries N, Germer J, Glücklich D, HÖNER G, LARYEa S \& SAUERborn J (2006): Ecological development of settlements - the case study Valley View University, Accra, Ghana. - Res. Dev. Sub-Sahara Africa 1: 2-5.

GELLER G \& GLÜCKLICH D (2012): Sustainable rural and urban ecosystems: design, implementation and operation manual for practice and study. - Springer, Heidelberg, 179 p. 
Germer J, Boh MY, Schoeffler M \& Амоah P (2010): Temperature and deactivation of microbial faecal indicators during small scale co-composting of faecal matter. - Waste Management 30: 185-191.

Gough KV \& YANKson PWK (2000): Land markets in African cities: The case of peri-urban Accra, Ghana. - Urban Studies 37: 2485-2500.

HALl JB \& SwaINe MD (1976): Classification and ecology of closed-canopy forest in Ghana. - J. Ecol. 64: 913-951.

HALl JB \& SwaINE MD (1981): Distribution and ecology of vascular plants in a tropical rain forest - Forest vegetation in Ghana (Geobotany). - Dr. W. Junk Publishers, The Hague, $383 \mathrm{p}$.

HAWTHORNE WD \& JONGKIND CCH (2006): Woody plants of Western African Forests - A guide to to the forest trees, shrubs and lianes from Senegal to Ghana. - Kew Publishing, Richmond, 1023 p.

Hutchinson J \& DALZIEL JM (1954-1972): Flora of West tropical Africa. Volumes I-III. 2nd edn. rev. by KeAY RW, HePPER FN (eds.). - Crown Agents for Oversea Government and Administrations. The Whitefriars Press, London, 1946 p.

IRVINE FR (1961): Woody plants of Ghana with special reference to their uses. - Oxford University Press, London, 868 p.

JeníK J \& HaLl JB (1976): Plant communities of the Accra plains. - Folia Geobot. Phytotx. 11: 163-212.

LIEBERMAN D (1982): Seasonality and phenology in a dry tropical forest in Ghana. - J. Ecol. 70: 791-806.

LiEBERMAN D \& Li MG (1992): Seedling recruitment patterns in a tropical dry forest in Ghana. - J. Veg. Sci. 3: 375382.

Lovell ST \& Johnston DM (2009): Designing landscapes for performance based on emerging principles in Landscape Ecology. - Ecol. Soc 14 (1): 44 [online].

LYLE JT \& WOODWARD J (1999): Design for human ecosystems: landscape, land use, and natural resources. - Island Press, Washington DC, 288 p.

Otte A, Simmering D \& Wolters V (2007): Biodiversity at the landscape level: recent concepts and perspectives for multifunctional land use. - Landscape Ecol. 22: 639-642.

Owusu-Mensa K (2009): Thirty Years of Valley View University in Ghana. - Manuscript, ASDAH, 20 p.

REDMAN CL \& JoNES NS (2005): The environmental, social, and health dimensions of urban expansion. - Popul. Environment 6: 505-520.

Selman P (2009): Planning for landscape multifunctionality. - Sustain. Sci. Pract. Pol. 5: 45-52.

Stepr JR, Jones EC, Pavao-Zuckerman M, Casagrande D \& ZARGER RK (2003): Remarkable properties of human ecosystems. Conserv. Ecol. 7(3): 11. [online]

United Nations (2010): World Urbanization Prospects, the 2009 Revision: Highlights. Department of Economic and Social Affairs, Population Division. - http://esa.un.org/unpd/ wup/Documents/WUP2009_Highlights_Final.pdf. Access date: 11/30/2013. 46p.

Vitousek PM, Mooney HA, Lubchenco J \& Melillo JM (1997): Human domination of earth's ecosystems. - Sci 277: 494-499.
Waldhardt R, Bach M, Borresch R, Breuer L, DieKÖtTER T, Frede, HG, Gäth S, GinZler O, GotTsChalk T, Jülich S, Krumpholz M, Kuhlmann F, Otte A, Reger B, Reiher W, Schmitz K, Schmitz PM, Sheridan P, SimMERING D, Weist C, Wolters V \& ZÖRner D (2010): Evaluating today's landscape multifunctionality and providing an alternative future: a normative scenario approach. - Ecol. Soc. 15 (3). 30 [online].

YANKSON PWK \& Gough KV (1999): The environmental impact of rapid urbanization in the peri-urban area of Accra, Ghana. - Danish J. Geogr. 99: 89-100.

YeboAh IEA (2000): Structural adjustment and emerging urban form in Accra, Ghana. - Africa Today 47: 61-89

YeвоAн, I.E.A., (2003): Demographic and housing aspects of structural adjustment and emerging urban form in Accra, Ghana. - Africa Today 50: 107-119.

\section{ADDRESSSES OF THE AUTHORS}

\section{Prof Dr. Dr. Annette Otte*}

Dr. Dietmar Simmering*

Division of Landscape Ecology and Landscape Planning, Justus-Liebig-University Giessen, IFZ, Heinrich-Buff Ring 26-32, D-35390 Giessen, Germany

E-Mail: annette.otte@umwelt.uni-giessen.de dietmar.simmering@umwelt.uni-giessen.de

* Authors to whom correspondence should be addressed:

\section{Solomon Addai}

Valley View University, Accra-Dodowa Rd. Mile 19 (near Oyibi), P.O. Box AF 595, Adenta, Ghana

\section{Gunther Geller}

Ecological Engineering Society (IÖV e.V.), Völkstraße 27, D-86150 Augsburg, Germany 